John Carroll University

Carroll Collected

2019 Faculty Bibliography

Faculty Bibliographies Community Homepage

$2-2019$

\title{
Why the Duty to Self-Censor Requires Social- Media Users to Maintain Their Own Privacy
}

Earl W. Spurgin

John Carroll University, espurgin@jcu.edu

Follow this and additional works at: https://collected.jcu.edu/fac_bib_2019

Part of the Ethics and Political Philosophy Commons

\section{Recommended Citation}

Spurgin, Earl W., "Why the Duty to Self-Censor Requires Social-Media Users to Maintain Their Own Privacy" (2019). 2019 Faculty Bibliography. 1.

https://collected.jcu.edu/fac_bib_2019/1

This Article is brought to you for free and open access by the Faculty Bibliographies Community Homepage at Carroll Collected. It has been accepted for inclusion in 2019 Faculty Bibliography by an authorized administrator of Carroll Collected. For more information, please contact connell@jcu.edu. 


\title{
Why the Duty to Self-Censor Requires Social-Media Users to Maintain Their Own Privacy
}

\author{
Earl Spurgin ${ }^{1}(0)$
}

\begin{abstract}
Revelations of personal matters often have negative consequences for social-media users. These consequences trigger frequent warnings, practical rather than moral in nature, that social-media users should consider carefully what they reveal about themselves since their revelations might cause them various difficulties in the future. I set aside such practical considerations and argue that social-media users have a moral obligation to maintain their own privacy that is rooted in the duty to self-censor. Although Anita L. Allen provides a paternalist justification of the duty that supports my position that social-media users are obligated to self-censor what they reveal about themselves, I justify the obligation through considerations that are more palatable to liberals than is paternalism. I accomplish this by arguing that the failure to self-censor often creates for others undue burdens that individuals are obligated morally not to create. In particular, social-media revelations often create undue burdens for those, such as employers and university personnel, who are obligated morally to respect individuals' privacy in their decision-making processes. I also demonstrate that this argument is not for a broad duty to self-censor, but, rather, for a narrow duty that applies to particular circumstances such as certain uses of social media.
\end{abstract}

Keywords Liberalism $\cdot$ Paternalism $\cdot$ Privacy $\cdot$ Self-censor $\cdot$ Social media $\cdot$ Undue burdens 


\section{Introduction}

Social media has made it much easier, and much more common, for individuals to reveal personal matters about themselves. Such revelations often have negative consequences for social-media users. The many examples include a teacher who was fired after posting that she should drown her students because she hated them, a teen who was fired after posting that her job was boring, a nurse who was fired after posting a photo of a patient, a doctor who was reprimanded after posting patient information, and airline employees who were fired after posting jokes about passengers and the conditions of airplanes (Branley 2013). Such negative consequences trigger frequent warnings, practical rather than moral in nature, that social-media users should consider carefully what they reveal about themselves since their revelations might cause them various difficulties in the future. Although I generally concur with such practical warnings, I will set them aside and argue that social-media users have a moral obligation to maintain their own privacy that is rooted in the duty to self-censor.

In the last several decades, ethicists have devoted considerable attention to the right to privacy, but have been relatively silent on whether individuals have a duty to self-censor that requires them to maintain their own privacy. This relative silence is not surprising since recent decades have provided ethicists with innumerable reasons to focus on the right to privacy. The exponential growth in the capabilities of governments, employers, educational institutions, healthcare providers, and others to monitor and record individuals' activities has produced a corresponding growth in ethical issues involving individuals' privacy.

A notable exception to this relative silence on the duty to self-censor is Anita L. Allen (2011). Allen uses paternalism to argue that, in some circumstances, the state should require individuals to maintain their own privacy. She writes, 'We should live some of our lives in private, some in public; and... there is often a role for government in requiring us to live this way.... [W]e... need government to help us preserve forms of privacy that are important to our lives but to which we may be unwisely indifferent' (2011, p. 194). Allen recognizes a duty to self-censor, and, in some circumstances, is prepared to have the state enforce it for individuals' own good.

Allen aside, ethicists who address privacy and information technology usually pursue a variety of questions related to the right to privacy. Many ask whether it is ethical for various institutions, such as governments, employers, educational institutions, and libraries, to monitor and/or restrict what individuals do through information technology (e.g., Coleman 2006; Garner 2012; Gorman 1998; Lau 2011; Lehavot 2009; McArthur 2001; Miller and Weckert 2000; Wyatt 2006). This includes monitoring individuals' e-mails, the websites they visit, and the items they post on social media, as well as using the findings of such monitoring to make employment, admission, legal, and other decisions about the monitored individuals.

Others address the collection and use of information (e.g., Charters 2002; Fulda 2012; Gotterbarn 1999; Klang 2004; Pollach 2005; Royakkers 2004; Tavani 1999, 2007). They ask whether it is ethical for institutions, such as corporations, to 
gather information about individuals while those individuals use information technology, engage in data mining to produce information about groups or individuals, or disseminate or disclose items individuals place on the Internet.

Still others address the ethics of psychological and social-science research into items available through information technology (e.g., Holley 2006; Øhrstrøm and Dyhrberg 2007; Pittenger 2003; Zimmer 2010). Often, their concern is whether those who place items on the Internet intend the items to be available for research purposes, and, thus, consent to their use in studies.

By and large, the disparate issues concerning privacy and information technology ethicists address have an important feature in common. They focus on whether institutions' various uses of information technology violate individuals' right to privacy. This suggests that these ethicists primarily are concerned with what institutions do with matters they discover about individuals on social media, not primarily with whether individuals have a duty to self-censor what they reveal about themselves on social media.

Although I generally concur with those who argue that it is not ethically permissible for institutions to use matters they glean from social media for decisionmaking purposes, like Allen I seek to demonstrate that social-media users ought to self-censor what they reveal about themselves. The directive to self-censor is not simply a practical recommendation. Those who violate it are not subject merely to the criticism that they are acting unwisely with respect to their own interests. They, instead, violate a moral duty and rightfully are subject to moral condemnation. My argument for that moral duty should be more palatable to liberals than is Allen's since, rather than deriving the duty from paternalism, I rest it on our moral obligation not to create undue burdens for others. Individuals' failure to self-censor often creates undue burdens for others that those individuals are obligated morally not to create. In particular, social-media revelations often create undue burdens for those, such as employers and university personnel, who are obligated morally to respect individuals' privacy in their decision-making processes regarding hiring, firing, admission, dismissal, and the like.

\section{A Preliminary Matter}

My usage of the term 'self-censor' might differ from what many readers expect. In recent years, political theorists, legal scholars, and others have made significant contributions to academic literature through their works on self-censorship (e.g., Cook and Heilmann 2013; Festenstein 2015; Horton 2011; Lægaard 2007; Loury 1994; Marlin 1999; Sedler 2012; White 2012). Given the title of this paper, readers familiar with those works might expect my usage of 'self-censor' to coincide with the usage those works' authors employ. My usage, however, differs in an important way. This departure stems neither from a rejection of the authors' reasons for addressing self-censorship nor from a challenge to the authors' usage of the term 'self-censorship'. On the contrary, I am a sympathetic reader of those works who believes they engage a pressing social and political issue. Moreover, given the authors' purpose, I do not quibble with how they use the term. The departure stems, 
instead, merely from the fact that my overall purpose differs from those authors' purpose.

By referring to the authors' usage of the term, I do not suggest that all of the authors define the term 'self-censorship' identically. I recognize that the definition of the term often is a matter of dispute among them. Nevertheless, the matters the authors address, as well as their reasons for addressing them, coalesce. Essentially, the authors' purpose is to examine political concerns about self-censorship. No matter the definitions of 'self-censorship' they hold, they all wish to determine whether self-censorship has a place in liberal democracies.

That determination is a particularly pertinent issue for two reasons. First, selfcensorship seemingly is antithetical to one of the most important tenets of liberal democracy: the special significance afforded freedom of expression. With that special significance in mind, the authors examine whether self-censorship has a corrosive effect on democracy by unduly restraining expression. Matthew Festenstein states well why the authors are concerned that self-censorship might have that corrosive effect. He writes, 'Self-censorship seems to... [constrain] citizens' ability to speak to each other, to speak truth to power and freely to express themselves. What gives rise to it are unacceptable and degrading relationships of power or influence' (2015, p. 2).

Second, there often is a tension between the value of unfettered expression and other values such as security, equality, and inclusion. Since liberal democracies seek to promote such values, the authors examine whether there can be circumstances where those values override the value of freedom of expression, thereby justifying self-censorship. Such considerations lead Festenstein to conclude, 'Our relation to self-censorship is (or should be) ambivalent, since the democratic values that underpin the criticism of self-censorship also suggest reasons it should be tolerated in some circumstances' $(2015$, p. 16). Such considerations also are why at least some of the authors are motivated by the controversies and violence that followed the Danish newspaper Jyllands-Posten and the French magazine Charlie Hebdo publishing cartoons of the Prophet Muhammad. Those authors examine whether considerations such as security, equality, and inclusion support claims that the publications should have censored themselves and not published the cartoons.

As important as it is to determine whether self-censorship has a place in liberal democracies, attempting to do so is not my purpose. Despite invoking the duty to self-censor, this paper is not an examination of the political concerns about selfcensorship. Its purpose is both broader and more modest. It is broader because my usage of the term 'self-censor' encompasses more of individuals' lives than does the usage employed by authors who examine self-censorship's political concerns. According to my usage, the question, 'Does individual $\mathrm{X}$ have a duty to selfcensor?', applies to circumstances beyond those that spawn worries that selfcensorship corrodes democracy by unduly restraining freedom of expression. This paper's purpose is more modest because, although the question applies to potentially-corrosive-of-democracy circumstances, I do not seek to answer the question regarding those circumstances. I, instead, seek only to answer the question in the narrowly defined context of social-media users revealing personal matters about themselves. 
Although we have differing purposes, there are some overlaps between how I use the term 'self-censor' and how those who examine political concerns about selfcensorship use it. Philip Cook and Conrad Heilmann distinguish two types of selfcensorship. They write:

... public self-censorship refers to a range of individual reactions to a public censorship regime.... [I]ndividuals internalise... aspects of the public censor and then censor themselves.... [P]rivate self-censorship is the suppression by an agent of his or her own attitudes where a public censor is either absent or irrelevant. [It] is a process of regulation between what an individual regards as permissible to express publicly, and that which he or she wishes to express publicly. (2013, p. 179)

Although the question, 'Does individual X have a duty to self-censor?', applies to both of Cook and Heilmann's types, their private self-censorship captures the context of social-media revelations about which I am concerned. My position that social-media users have a duty to self-censor their revelations is not based on the idea that users are obligated to internalize the directives of some public censorship regime. It, instead, is based on the idea that living morally obligates users to censor their revelations that, if not censored, impose undue burdens on others.

Despite the fact that Cook and Heilmann's private self-censorship is the kind of self-censorship with which I am concerned, there are two reasons not to conclude that my usage of 'self-censor' is identical to the usage employed by those who examine political concerns about self-censorship. First, my overall purpose departs from Cook and Heilmann's. They present the concept of private self-censorship so that they can distinguish it from public self-censorship. They draw the distinction so that they can demonstrate that only public self-censorship raises the political concerns at issue. They write, '... the principles of free speech apply only to public self-censorship... [because] the intrapersonal conflicts that... characterize private self-censorship are not subsumable under normative notions of freedom of speech' (2013, p. 191). This demonstrates that Although Cook and Heilmann's usage of 'self-censor' overlaps with mine, they hold that the type of self-censorship that applies to this paper's subject does not raise the potentially-corrosive-of-democracy issue that they and the other authors examine.

Second, some of the authors at issue hold that given their political concerns, cases captured by Cook and Heilmann's private self-censorship actually are not cases of self-censorship at all. Festenstein writes:

The political conception of self-censorship... is constituted not only by nonperformance of a speech act but also by non-performance underpinned by a certain kind of explanation, in terms of a problematic power or influence relationship. This account allows us to distinguish political self-censorship from other forms of expressive self-restraint, including prudential silence [and] ethical tact... (2015, p. 3)

Cases of private self-censorship lack the problematic relationships between selfcensoring individuals and powerful or influential parties that are necessary to qualify them as cases of political self-censorship that raise the potentially-corrosive- 
of-democracy issue. Thus, my usage of self-censor differs from Festenstein's and like-minded authors' usage.

The preceding considerations demonstrate two main points. First, my examination of whether social-media users have a duty to self-censor departs from examinations of political self-censorship with which readers might be familiar. Second, my examination concerns a matter that falls under what Festenstein terms 'expressive self-restraint'. Thus, unlike him, I use the term 'self-censor' in a broad manner that captures moral matters beyond what he terms 'political selfcensorship'. More precisely, I employ the term to address a particular moral duty's application to a given context.

\section{The TMI Restriction}

For the most part, ethicists who suggest that there is a duty to self-censor, as I conceive it, have in mind an uncontroversial sense of the duty. George G. Brenkert writes, 'The person who... makes a practice of revealing his most intimate thoughts and feelings to unconcerned strangers may be condemned... for his refusal to treat such matters as private...' (1981, p. 22). Brenkert does not develop this idea, however, for two reasons. First, his primary purpose is not to examine the duty to self-censor, but, rather, is to demonstrate both that employees have a right to privacy and the extent of that right. Second, his motive for suggesting that there is a duty to self-censor is to demonstrate that privacy is a function of the relationship of the parties in question. There is no set of matters that are rightfully private in all contexts. Rightfully private matters vary among relationships according to what is necessary for the parties involved to perform their roles in those relationships.

Richard D. Mohr writes, 'In all societies there are obligations flowing from customs and mores to keep some activities, possessions, thoughts and things out of the public eye' (1987, p. 58). Although Mohr provides some examples of those obligations across cultures, like Brenkert, his purpose is not to examine the duty to self-censor. His purpose, instead, is to provide an argument that derives, from the duty to self-censor, the privacy right that insulates our sex lives from government interference. Because we are obligated to pursue our sexual activities in private, we have a corresponding right to privacy with respect to those activities. Mohr writes, '... across the range of actions for which there is an obligation to privacy there is generated from that very obligation in turn a right to privacy. For society cannot consistently claim that these activities must be carried out in private... and yet retain a claim to investigate such activities and so, to that extent, make it public behavior' (1987, p. 59).

Laypersons also acknowledge an uncontroversial sense of the duty to self-censor. When we share with others personal matters that they believe we should keep to ourselves, they often reply with the widely known refrain, 'That's too much information!' In fact, a simple reference to the TMI acronym quickly informs us that we have shared too much about ourselves. Like ethicists, laypersons recognize that the sharing of personal matters is not a 'no-holds-barred' activity. Even in discussions among close friends, we expect a certain amount of self-censoring 
during our interactions. Many of us have that friend who is prone to taking a discussion one step too far by revealing some personal matter that the rest of us later wish we did not know. When that happens, we wish the friend were more adept at self-censorship.

I call this uncontroversial sense of the duty to self-censor the 'TMI restriction' on our behavior. Strictly speaking, the restriction is a subset of the duty to self-censor in that it requires us to keep certain matters private. It is a special subset of the duty, however, that captures many situations that most are reticent to classify as violations of a duty. Imagine one who, at a dinner party, describes to others in vivid detail the preparation one endured for a colonoscopy. Others at the dinner table likely view this as a violation of the TMI restriction, and perhaps even say to the offending party things like, 'that's disgusting', 'please, not at the table', or 'that's too much information'. Those same others likely are reluctant to classify the behavior as a violation of a duty, however, because we typically apply the term 'duty' to more pressing matters. Even though, strictly speaking, one violates the duty to self-censor by telling such a story in that context, there is little controversy over the case. The behavior in the case is so unimportant that others are reluctant to debate whether the behavior violates a duty.

The preceding example illustrates that the kinds of relatively uncontroversial cases the TMI restriction captures have at their core a notion that plays a significant role in the substantive argument of this paper. That notion is the relevance of creating undue burdens for others. Free-speakers at dinner tables cause no significant burdens for others. Their topics might disgust others, and might even cause some to walk away from the table. Although that is a burden in some sense, it is not a significant burden. The lack of a significant burden for others produces our reticence to categorize free-speakers' behavior as violating the duty to self-censor in any pressing way. The lack of a significant burden also is why such cases are uncontroversial.

\section{A More Controversial Sense of the Duty to Self-Censor}

Creating burdens for others in any context is justified morally only if there is a good reason to create them. Absent a good reason for creating a given burden in a given context, the burden is undue. If a burden is undue, then one is obligated not to create it. This moral requirement grounds a sense of the duty to self-censor that applies to cases that are more controversial than are those the TMI restriction captures. The undue-burden concept provides a criterion for determining which of the countless instances where individuals reveal personal matters, including those involving social media, violate the duty to self-censor. Revelations of personal matters that create undue burdens for others violate the duty. Those that do not might be imprudent or immoral for other reasons, but they do not violate the duty to selfcensor that I proffer. 


\section{The Extent of the Duty to Self-Censor}

Although I argue that the undue-burden concept grounds a duty to self-censor, I hold that neither social-media users nor individuals in general have a broad duty to selfcensor. A broad duty to self-censor would come at too great individual and societal costs. Persons who self-censor too readily fail to explore new ideas and modes of living from which they, as well as society as a whole, might benefit. Similarly to the loss of privacy, broad self-censorship thwarts individual pursuits, innovation, and growth. Some ethicists see the value of privacy as providing a sphere in which we can think, act, and express ideas without fear of judgment. Jeffrey L. Johnson writes, 'The function of privacy... is to isolate certain limited and culturally defined aspects of the individual's life as being morally and legally protected from the evaluative judgment of others' (1989a, p. 157). Thomas Nagel writes, 'The awareness of how one appears from outside is a constant of human life... But there are aspects of life which require we be free of it, in order that we may live and react entirely from the inside' (1998, p. 18). Similarly to how we need freedom from the judgment of others in order to explore new ideas and modes of living, we also need freedom from self-judgment in order to explore those things. Similarly to how we often are too reticent to think or act outside the mainstream if we know we are subject to the constant judgment of others, we also often are too reticent to explore new ideas and modes of living if we too readily, or too often, judge ourselves.

The individual and societal costs of broad self-censorship are similar to those John Stuart Mill argues result from state and societal censorship (1978 [1859], ch. 2, esp. pp. 16-17, 33-38). He argues that society pays one of two costs if it censors a deviant view. If the deviant view is true or partially true, society loses access to the truth, something that Mill sees of obvious value. If the deviant view is false, society loses the value gained by confronting a false idea with the truth. That value lies in maintaining the 'living' nature of the truth and preventing it from lapsing into mere dogma. Broad self-censorship is subject to similar costs. If one self-censors too readily, or too often, one does not explore ideas and modes of living that might be beneficial. One might not find the idea or mode of living that is more true to one's, or society's, deep-seated commitments, or one might not reinforce why one's current idea or mode of living actually is most true to one's, or society's, deepseated commitments.

John Horton describes another concern that is applicable to broad self-censorship. A given instance of self-censorship might actually be state or societal censorship by proxy. ${ }^{1}$ One might have internalized state or societal restrictions to such an extent that one actually is '... no more than a tool or cipher of... the person who is really the source of the censorship...' (2011, p. 101). He adds that such self-censorship '... disguises the real source of the censorship...' and '... may work to undermine the agency of the self-censor through subverting the deliberative process in a way that straightforward censorship characteristically does not' (2011, p. 101).

\footnotetext{
1 Cook and Heilmann provide a somewhat different account of self-censorship by proxy when they address private self-censorship (2013, pp. 187ff.). Festenstein examines their account (2015, pp. 6ff.).
} 
Garry C. Gray presents a case study that demonstrates how the costs of selfcensorship can arise through censorship by proxy (2013). Gray conducted a twohour interview with a medical professor about his first experience with industryfunded, pharmaceutical research. During the interview, the professor indicated that he felt a motivation to self-censor. He said, 'I am upsetting the apple cart, potentially, but I don't know what they're going to do. If we come up with something and say, "Oh you know what? It doesn't hit where you think it does"-I mean, that's a scientific truth. And the question is, maybe I'll never get another dollar from them, potentially' (2013, p. 631). This motivation can produce two forms of self-censorship for industry-funded researchers. Both clearly come with societal costs. First, researchers might exercise what Gray terms 'self-censorship by nondisclosure' simply by keeping to themselves findings that are contrary to the interests of the firms that fund their research (2013, p. 631). Second, researchers might exercise what Gray terms 'self-censorship by narrowing the scope' which is '... deliberately avoiding the discovery of relevant information. This is done by strategically constraining the scope of the research design' (2013, p. 632). Both forms of self-censorship cost society access to scientific truths. The former suppresses already-discovered truths, while the latter suppresses potential discoveries of truths.

Because of the problems with a broad duty, I adopt a narrow duty to self-censor. Without good reasons, individuals should not self-censor what they do, the things they say, or how they live. Despite being narrow, however, the duty to self-censor captures more than the uncontroversial matters of the TMI restriction. The duty captures those additional matters because refraining from creating undue burdens for others is a good reason to self-censor.

Although this paper's purpose is not to provide an exhaustive account of the various circumstances in which the duty to self-censor arises, it is important to acknowledge that the social-media revelations with which I am concerned are not the only circumstances in which the duty might arise. The duty applies to many circumstances that involve neither social-media nor personal matters. Absent overriding considerations, one has a duty to self-censor whenever not doing so produces undue burdens for others. A patron who talks incessantly during a play creates undue burdens for both other patrons and the performers, and, thus, has a duty to self-censor by refraining from talking during the performance. The duty hinges on the undue burdens on others that the patron's talking causes, not on whether the patron is speaking about personal matters. The factor that determines whether one has a duty to self-censor in any situation, whether or not the situation involves social media or personal matters, is whether one's failure to self-censor creates undue burdens for others that are not overridden by other considerations. Since social-media users often create undue burdens for others when they do not maintain their own privacy, they have a duty to self-censor what they reveal about themselves. 


\section{Undue Burdens as Contextual Matters}

Determining whether given burdens are undue is a complex matter. There is no simple definition or formula by which we can easily separate undue burdens from those that are not. This is because whether a burden is undue is not a function of how great or small the burden. A small burden might be undue, and a great burden might not. Whether a burden is undue, instead, is a contextual matter. It is a function of the parties' roles and activities in the context in which the burden is imposed.

It is easy to classify some burdens. Grading papers is a burden, but, since it is a justifiable part of the profession I chose, it is not undue. Given my discipline, there are good reasons to require that I assign my students to write papers, and, thus, good reasons to burden me with grading those papers. Requiring that I teach a biology course, however, would impose on me an undue burden. Since I am not a biologist, there is no good reason to burden me with teaching such a course. Patients' difficulties describing their symptoms is burdensome for physicians, but justifiably are a part of physicians' chosen profession. Since patients typically lack medical expertise, it is reasonable to expect they will have such difficulties. This reasonable expectation provides a good reason to burden those who choose to become physicians with enduring those difficulties. Requiring physicians to provide religious counseling, however, would be an undue burden. Since physicians likely are not trained in religion, there is no good reason to burden them with helping patients work through religious matters. The burdens in all these cases are easy to classify, but that ease has nothing to do with how great or small the burdens. The ease stems from the fact that the burdens clearly are, or are not, justifiably part of the roles and activities at issue.

Unfortunately, cases of individuals creating burdens for others, especially those where individuals reveal personal matters about themselves, typically pose greater challenges than do the preceding cases. Their contexts often involve roles and activities the justifiable demands of which are difficult to determine. ${ }^{2}$ Classifying the burdens in such cases requires making those difficult determinations. Needless to say, this paper cannot make those determinations for all the possible contexts in which persons reveal personal matters. Nevertheless, engaging some of those contexts demonstrates how the undue-burden concept provides a criterion for determining when personal revelations, including those on social media, violate the duty to self-censor.

Suppose Jane is a research study's principal investigator and Joe is one of the study's many subjects. The study began with Jane meeting one-on-one with each subject so that she could acquire from the subjects necessary background information. The study's purpose necessitated acquiring information about the subjects' basic likes and dislikes. When Jane asked Joe what kinds of activities he enjoys, he replied, 'I like virtual-child pornography. Mind you, I'd never look at the real thing, but I like the computer-made pictures'. Although Jane kept her

\footnotetext{
2 The political concerns about self-censorship often complicate the contexts. An individual who publicly protests against a governmental policy likely creates burdens for others such as the individual's employer, coworkers, and family. When determining whether those burdens are undue, political concerns, such as the role of free speech in liberal democracies, are among the many matters that we must take into account.
} 
composure and completed the meeting, she was troubled afterwards. Because she dreaded the burden of trying to maintain her objectivity about him, she wondered whether she should drop Joe from the study. After considerable thought, Jane decided to keep Joe in the study and do what she must in order to maintain her objectivity.

Although Joe's predilection raises other moral questions, the undue-burden concept does not capture Joe's revelation. Whether or not his answer provided the kind of information Jane actually was seeking, Joe merely answered the question she asked. No matter how troubling Jane finds subjects' responses to her questions, Jane's researcher role requires her to cope with the information she encounters. Her role also requires her to respond to the situation as she did. Removing subjects because of their various predilections threatens the research's integrity by arbitrarily shaping the subject pool. Thus, the duty to self-censor does not apply to Joe's revelation in this context.

Suppose, however, that the context is different. Instead of being researcher and subject, Jane and Joe are coworkers. Even though the pair merely are friendly acquaintances, the nature of their work and their close proximity in the workplace make it inevitable that they have conversations unrelated to their work. Much to Jane's surprise, Joe began one such conversation by blurting out his predilection. Unsurprisingly, Jane was troubled by the revelation and finds it burdensome to continue working in close proximity to Joe.

The undue-burden concept captures Joe's revelation in this context. Even when a workplace allows for conversations unrelated to work, certain personal revelations create undue burdens. Among them are those involving subject matters that are inappropriate for the workplace. Other moral questions about Joe's predilection aside, the subject matter of Joe's revelation renders it inappropriate for the workplace. Since workplaces have a history of sexual harassment and discrimination, Jane justifiably was troubled by Joe beginning a conversation in the fashion he did. Even if some conversations of a sexual nature are permissible morally in the workplace, Joe's predilection potentially is too disturbing to be among them. Since nothing in the pair's roles or activities justifies Joe creating for Jane the burden of enduring knowledge of his predilection, the burden was undue. Since the burden it created was undue, the revelation violated the duty to self-censor.

Consider the same context, but a different revelation expressed in a different manner. Instead of revealing a morally questionable sexual predilection, Joe revealed that his deceased father was the Imperial Wizard of the Ku Klux Klan for much his adult life and remained active in the Klan up until his death a few years ago. He did not simply blurt it out, but, rather, told Jane when she innocently asked about Joe's family. Even though Joe said he disapproves of his father's membership of the group, he spoke highly of his father's character and expressed deep affection for him. Jane was troubled by what she learned. Since many of her ancestors suffered at the hands of the Klan, she cannot understand how anyone can hold in high esteem the character of a person who is part of such a hateful, violent group. Even though she knows Joe was not to blame for his father's beliefs and actions, she finds it difficult to think of Joe as she did prior to the revelation. 
It is easy to understand Jane's troubled feelings, and there is no reason to respond to them with anything other that sympathy and compassion. Nevertheless, the undue-burden concept does not capture Joe's revelation. Joe merely responded truthfully to an innocent question posed by a coworker. Life is such that we often are burdened by our interactions with others even when neither they nor we act wrongly. This is one of those unfortunate instances. Although there may be reasons, such as sensitivity's demands, why Joe should have opted not to tell Jane about his father's Klan affiliation, he did not violate the duty to self-censor by doing so.

A slight change in the context, however, complicates matters in a way that moves us toward considering social-media revelations. Suppose that, instead of being coworkers, Jane is Joe's supervisor. This increases her burden in a significant way. She no longer merely must work alongside Joe, but, also, she must evaluate him. Her burden now is similar to that in the researcher case. Just as Jane the researcher bore the burden of maintaining her objectivity about Joe the subject despite knowing about Joe's predilection, Jane the supervisor bears the burden of evaluating fairly Joe the employee despite her troubled feelings caused by Joe's revelation about his father's Klan affiliation.

Again similarly to the researcher case, the burden Jane bears in this case is not undue. As do many ethicists, I accept something like Brenkert's position that employers are obligated to consider only job-relevant matters when they make employment decisions (1981). Jane is obligated not to hold Joe's revelation against him unless its subject matter affects his ability to perform his job duties. Such would be the case if somehow internalizing his father's beliefs caused Joe to mistreat African-American coworkers and customers. There is no such internalization in this case, however, and there is no reason to assume his father's beliefs affect Joe's actions. Thus, despite her troubled feelings, Jane still is obligated to evaluate Joe fairly. The burden Jane bears is not undue simply because his revelation makes it harder for her to evaluate him fairly. After all, the burden arose by Joe truthfully answering an innocent question Jane posed to him. Joe did nothing untoward by so answering his supervisor's question.

This reasoning has an implication for social-media revelations that many readers might find surprising. Despite concluding that Joe's revelation did not create an undue burden for Jane, the basis of that conclusion produces the opposite conclusion about many social-media revelations. The following subsection explains why.

\section{Undue Burdens and Social-Media Revelations}

Although this is not the only possible way in which the duty to self-censor might arise for social-media users, the duty often arises when others are obligated to respect users' privacy. This is because, unlike the previous subsection's last case, social-media users' revelations often create undue burdens for others who are obligated to respect users' privacy. I take as a given that individuals have a right to privacy that governments, employers, educational institutions, and the like are obligated to respect. Individuals who hold the right to privacy are obligated not to create undue burdens for others who are obligated to respect those individuals' right to privacy. Social-media users, then, have a duty to self-censor what they reveal 
about themselves when the failure to do so creates undue burdens for others who are obligated to respect the users' privacy.

Most ethicists hold that privacy promotes a value that is necessary for persons to flourish, though their accounts of that value often disagree. Those accounts fall into three broad categories. Some argue that the value of privacy is that it allows us to demarcate our various relationships (e.g., Benn 1975; Fried 1970, ch. IX; Gerstein 1978; Moore 2003; Rachels 1975). By sharing with person X matters about oneself that one does not share with person $\mathrm{Y}$, one produces a more intimate relationship with $\mathrm{X}$ than with $\mathrm{Y}$. Others argue that privacy allows us to pursue our lives as we determine and develop our own identities or conceptions of who we are or ought to be (e.g., Corlett 2002; Gross 1980; Kupfer 1987; Parent 1983; Reiman 1976). Without privacy, one is subject to various forms of force or coercion, often real but sometimes only perceived, that prevent one from developing an autonomous self. Still others argue that privacy provides a sphere of life in which we can behave in various ways, share ideas, express our feelings, and comment on others without fear of judgment (e.g., Johnson 1989a, b, 1992; Nagel 1998). It allows us to try out new ideas and modes of living.

Elsewhere, I argue that each of those individual values of privacy, by itself, is insufficient to explain the true value of privacy (2006). I write:

The value of privacy is multifarious and contextual. The value of privacy for a person qua client in psychotherapy may be quite different from the value for a person qua employee or qua citizen in a liberal democracy. Moreover, the value in each of those contexts has multiple aspects, many of which may or may not come into play for a particular person. The value of privacy varies according to both the context in which it is considered and the circumstances a particular person brings to that context. (2006, p. 247)

If the preceding is correct, it helps demonstrate the complementary roles of the duty to self-censor and privacy. Earlier, I argued that the undue-burden context is a contextual matter. Whether the burden $\mathrm{X}$ imposes on $\mathrm{Y}$ is undue depends on the context in which $\mathrm{X}$ imposes the burden. It is a function of whether the burden is part of Y's role in $\mathrm{X}$ and Y's relationship. The value of privacy is similarly contextualized, rendering the value of privacy and undue burdens counterparts. Just as the true value of privacy varies according to the context at issue, what qualifies as undue burdens varies according to the same context.

This has an important implication for the matters the duty to self-censor often captures. If we hold that various institutions are obligated to respect individuals' privacy so that those individuals can garner the value of privacy, as the particular contexts determine it to be, then we also should hold that those individuals are obligated not to create undue burdens, as the particular contexts determine them to be, for the institutions that must respect their privacy. In this way, the duty to selfcensor often is the flipside of the right to privacy. If institutions are obligated to take certain steps to allow individuals to garner the value of privacy, those individuals are obligated not to make it unduly burdensome for institutions to fulfill that obligation. This reasoning is not unique to obligations related to privacy. Whenever one has an obligation, others, especially those to whom one owes the duty, are 
obligated not to make it unduly difficult for one to fulfill that obligation. Although I am obligated to obey posted traffic signs when I drive, governments are obligated to construct and locate those signs in ways that do not make it unduly difficult for me to see and read the signs. Similarly, although universities in the United States are obligated legally to make accommodations for students with various kinds of disabilities, students are obligated not to make it unduly burdensome for universities to fulfill those obligations by demanding unreasonable accommodations.

Social-media revelations often make it unduly burdensome for various institutions to fulfill their obligations to respect individuals' privacy. Consider employers and educational institutions. As the analysis of the previous subsection's last case suggests, both are obligated to consider only relevant matters when making their respective employment or admissions decisions. If they seek out irrelevant, personal matters about applicants, they violate the applicants' privacy. Many social-media revelations, however, make it practically impossible, and, thus, unduly burdensome, for those institutions to ignore irrelevant, personal matters. The advent of social media means that face-to-face contact, communication over the telephone, written communication, and the like no longer are necessary to reveal such matters. In a few seconds, individuals can reveal personal matters to many more people than once was possible. Then, in merely seconds more, those who access the revelations can share them with still others, beginning a seemingly unending process of disseminating the revealed matters. This broad dissemination greatly increases the frequency of employers, universities, and others accessing, either intentionally or unintentionally, individuals' personal matters.

Consider the teacher who posted that she should drown her students. Surely, she merely was venting after a particularly bad day or set of days. Such venting, rather than being a job-relevant matter that her employer should take into account, likely is a rather healthy way, in mental-health terms, for the teacher to release tension and explore the circumstances of her life and career. The very fact that she had that thought has the potential to encourage her to explore matters such as whether she interacts with her students in the most productive ways available, takes the proper steps to cope with the stresses of teaching, and effectively separates students' behavior from her self-concept. By itself, the teacher's thought is not a job-relevant matter warranting her firing. Nevertheless, should students, parents, guardians, and others read her post and call for her dismissal, school administrators would be required to use much of their valuable time defending the teacher's right to have her thought on the grounds that such a thought is not a job-relevant matter.

Likewise, the fact that the teen posted that she finds her job boring is not a jobrelevant matter since, by itself, it says nothing about how well she actually performs her job duties. Her supervisor, however, must use valuable time making that case on her behalf should others who desire the position or higher-level management read her post and object to her continued employment.

Similarly to the teacher, surely the airline employees who posted jokes about passengers and the conditions of airplanes were simply venting and commiserating. Just as professors often vent and commiserate about the quality, immaturity, laziness, and naïveté of their students by making jokes and unwarranted, exaggerated claims about students and their work, other employees, regardless of 
the type of workplace, similarly vent and commiserate. Just as it is healthy for professors to so vent and commiserate, it also is healthy for other employees. In neither case are the venting and commiseration job-relevant matters. When those professors or employees use social media for venting and commiserating, however, their superiors must use valuable time to defend them against the charges of customers, students, parents, guardians, and others who become enraged after reading their posts.

In all these cases, the employees, students, and professors have a right to privacy with respect to their thoughts, venting, and commiseration since those things are not job- or admission-relevant. Nevertheless, they violated their obligations not to create undue burdens for others for two reasons. First, each of them could have engaged in their thoughts, venting, and commiseration in ways that maintained their own privacy. They could have chosen ways that did not affect those who employ or admit them. Second, given how they proceeded, someone must bear the burden of making the case that their posts are not job- or admission-relevant. That burden falls not on them, but, rather, on those who employ or admit them. Since the burden is undue, placing it on those others violates a moral obligation. If employees, students, professors, and others wish to retain the right to privacy that obligates decisionmakers to consider only relevant matters, they should honor their obligation not to make it unduly burdensome for those decision-makers to respect their right to privacy.

Those two reasons demonstrate why the undue-burden concept often produces the opposite conclusion about social-media revelations from the conclusion it produces for the previous subsection's last case. In that case, Joe did not choose on his own to reveal the information about his father. Jane, his supervisor, instigated the troubling revelation, albeit unintentionally and innocently, by asking Joe about his family. Whether or not Joe should have withheld the information for other reasons, we are not justified in concluding that Joe created an undue burden for Jane simply by answering truthfully her own innocent question.

\section{A Likely Objection}

One might raise a twofold objection to my position. First, one might argue that the burden on decision-makers that I describe is not undue at all. Decision-makers assume that burden by accepting voluntarily their decision-maker roles. The obligation to respect the privacy of those about whom they must make judgments is among the many obligations assumed by those who accept certain roles. Moreover, decision-makers often are required to explain to others why they act as they do. The burden I describe merely is one of those instances. It is no more burdensome for decision-makers to explain why they ignore irrelevant matters when making their judgments than it is for them to explain why they consider or ignore any other factors in their decision-making processes. Second, even if the burdens I describe are undue, they arise only in cases where others have read the posts and challenge the decision-makers' judgments. Decision-makers still are obligated not to use 
social media to seek out irrelevant matters pertaining to those about whom they must make judgments.

This objection fails to account adequately for many of the practical matters that decision-makers often face. The most significant possible negative consequences a decision-maker faces stem from others determining that the decision-maker made an incorrect decision. Granted, possibly being wrong is a risk all decision-makers face when they adjudicate matters, and all good decision-makers learn to deal effectively with the fallout of bad decisions. Ignoring the social-media posts by those about whom they make judgments, however, places decision-makers in much more vulnerable positions than do most other factors that could cause them to make bad decisions. Because social-media revelations are accessible so easily, if one does not take into account social-media revelations when making a decision that turns out to be bad, it raises the specter of legal action against, and public-relations fallout for, one's institution.

Imagine an employer who learns of an applicant's post of a video taken at a party in which the applicant clearly is intoxicated and behaving in a disgusting manner. Suppose the employer reasons as follows: 'What employees do during their free time is none of my business. I have no reason to believe that the applicant would behave that way at work. In fact, the applicant's behavior in the interview indicated quite the opposite. The question before me is whether this applicant is the best qualified for the position, not whether I find objectionable the behavior in the video'. The employer concludes that the applicant is the best qualified and hires the applicant. A few weeks later, the new employee, because of drunkenness, causes a workplace accident that seriously injures several customers and other employees. Clearly, the injured persons' attorneys would relish learning that the employer had seen the video prior to hiring the employee. Those attorneys likely would argue that the employer should have foreseen the possibility of the employee arriving at work drunk and causing such an accident. Since the judge or jury hearing the case was not privy to the interview that led the employer to believe the employee would not exhibit at work the behavior in the video, that argument likely would have considerable force. Meanwhile, the employer's attorneys would have a difficult time explaining away the so-called 'bad fact' of the employer having seen the video by arguing that it is a matter the employer was obligated morally to ignore during the hiring process. A similar legal scenario would ensue in the unlikely event that the venting teacher acted violently against a student after school officials ignored her social-media rant about her students.

In a significant way, social-media posts like the described video and the teacher's rant are similar to a phone call in a public venue. As I write this in a coffee shop, another customer is speaking loudly into his phone. Although I believe I have an obligation to respect his privacy, he is making it practically impossible for me to do so. His voice simply is too loud for me to ignore. The employer and the school officials are in similar situations. It is not practically possible for them to ignore the posted video and rant because of the serious threat potential legal action or publicrelations fallout pose for their respective business and school. Although the practical impossibility is not a physical/psychological impossibility like mine in the phone case, it is just as significant. Decision-makers are obligated to protect their 
institutions from foreseeable harms, and potential legal liabilities or possible publicrelations fallouts often are foreseeable when those decision-makers ignore socialmedia revelations.

Regarding the claim that decision-makers are obligated not to use social media to seek out irrelevant matters pertaining to those about whom they must make judgments, I could not agree more. This, however, does not account for the fact that decision-makers often discover social-media users' revelations unintentionally. Decision-makers are individuals with rights too, and, thus, they have the right to use social media just as do those about whom they make judgments. As they use social media, they easily can discover such revelations by 'stumbling' upon them accidently, or by others bringing the revelations to the decision-makers' attention. When this happens, decision-makers face the described practical impossibility of ignoring the posted matter even if that matter, by itself, is not relevant to the decision-making process. Thus, even though decision-makers are obligated not to use social media to seek out irrelevant matters concerning those about whom they must make judgments, social-media users still are obligated to self-censor their revelations so as to avoid creating undue burdens for those decision-makers.

\section{Conclusion}

The proffered argument for a narrow duty to self-censor that applies to social-media users is at odds with Allen's argument. She summarizes her position in this way:

Privacy is too important to be left entirely to chance and fleeting taste.... $[\mathrm{W}] \mathrm{e} . .$. need government to help us preserve forms of privacy that are important to our lives but to which we may be unwisely indifferent. We may be unwisely indifferent because we are young,... busy, or... unfamiliar with the risks of data collection, sharing and storage that come with the technology we enjoy without understanding. (2011, p. 194)

Allen's justification of the duty to self-censor is rooted in judgments about both what actually is best for individuals and individuals' frequent inability to recognize and act on what is best for them. This firmly situates her justification within paternalism. Allen acknowledges both the situation of her justification within paternalism and that paternalism is anathema to many liberals. She writes, 'The recoil at the spectre of paternalism can be nearly instinctive for political liberals. But the modest paternalism defended here is consistent with, and indeed required by a robust, liberalism appreciative of the respects in which unchecked losses of privacy can render one nearly a slave to unforgiving masters' (2011, p. 194).

Admittedly, I am one of those liberals who recoil at the specter of paternalism. Despite that, I do not challenge Allen's judgment that liberalism sometimes is consistent with, or even requires, modest paternalism. That judgment might well be correct. Moreover, I do not challenge her claim that individuals, especially socialmedia users, often do not fully recognize or appreciate the harm they might cause themselves by failing to self-censor. That claim is correct, and various aspects of my argument implicitly accept it. 
Despite not challenging those aspects of Allen's justification of the duty to selfcensor, there is an important reason why, if my argument is sound, the undue-burden justification of the duty should be more palatable to liberals than is Allen's. Suppose the truth, as I already have acknowledged might well be the case, of Allen's judgment that liberalism sometimes is consistent with modest paternalism. Even with that truth at their disposal, liberals are not justified in appealing to paternalism at will in order to support obligations regarding, or efforts to bring about, states of affairs that are consistent with liberalism. This truth justifies liberals' appeals to paternalism only in cases where there is no non-paternalist support available to which they can appeal. If my argument is sound, that necessary condition is not present in the case of social-media users' duty to self-censor since the undue-burden justification of the duty does not rest on paternalism. Moreover, liberals have another reason to find the undue-burden justification more palatable. It rests on this idea that liberals readily should endorse: Individuals should not create undue burdens for others.

Acknowledgements I am indebted to Andrew I. Cohen, Richard Dean, and an anonymous reviewer for their helpful suggestions.

\section{References}

Allen, Anita L. 2011. Unpopular privacy: What must we hide?. Oxford: Oxford University Press.

Benn, Stanley I. 1975. Privacy, freedom, and respect for persons. In Today's moral problems, ed. Richard Wasserstrom, 1-21. New York, NY: Macmillan Publishing Co.

Branley, Dawn. 2013. Fired via Facebook: Five social media mistakes to avoid. The Cyber Psyche. http:// thecyberpsyche.wordpress.com/2013/08/08/fired-viafacebook-five-social-media-mistakes-to-avoid/.

Brenkert, George G. 1981. Privacy, polygraphs and work. Business \& Professional Ethics Journal 1: 19-36.

Charters, Darren. 2002. Electronic monitoring and privacy issues in business-marketing: The ethics of the double-click experience. Journal of Business Ethics 35: 243-254.

Coleman, Stephen. 2006. E-mail, terrorism, and the right to privacy. Ethics and Information Technology 8: 17-27.

Cook, Philip, and Conrad Heilmann. 2013. Two types of self-censorship: Public and private. Political Studies 61: 178-196.

Corlett, J. Angelo. 2002. The nature and value of the moral right to privacy. Public Affairs Quarterly 16: 329-350.

Festenstein, Matthew. 2015. Self-censorship for democrats. European Journal of Political Theory. https:// doi.org/10.1177/1474885115587480.

Fried, Charles. 1970. An anatomy of values: Problems of personal and social choice. Cambridge, MA: Harvard University Press.

Fulda, Joseph S. 2012. Written for the moment. Journal of Information Ethics 21: 21-26.

Garner, Martin L. 2012. For the sake of one child: Privacy, anonymity, and confidentiality in libraries. Journal of Information Ethics 21: 12-20.

Gerstein, Robert S. 1978. Intimacy and privacy. Ethics 89: 76-81.

Gorman, John. 1998. Monitoring employee Internet usage. Business Ethics: A European Review 7: 21-24.

Gotterbarn, Donald. 1999. Privacy lost: The net, autonomous agents, and 'virtual information'. Ethics and Information Technology 1: 147-154.

Gray, Garry C. 2013. The ethics of pharmaceutical research funding: A social organization approach. Journal of Law, Medicine \& Ethics 41: 629-634.

Gross, Hyman. 1980. Privacy and autonomy. In Philosophy of law. 2nd edn, ed. Joel Feinberg and Hyman Gross, 246-251. Belmont, CA: Wadsworth Publishing Company. 
Holley, Robert P. 2006. The ethics of scholarly research and the Internet: Issues of publication, privacy, and the right to speak. Journal of Information Ethics 15: 27-34.

Horton, John. 2011. Self-censorship. Res Publica 17: 91-106.

Johnson, Jeffery L. 1989a. Privacy and the judgment of others. The Journal of Value Inquiry 23: 157-168.

Johnson, Jeffery L. 1989b. Privacy, liberty and integrity. Public Affairs Quarterly 3: 15-34.

Johnson, Jeffery L. 1992. A theory of the nature and value of privacy. Public Affairs Quarterly 6: 271-288.

Klang, Mathias. 2004. Spyware-The ethics of covert software. Ethics and Information Technology 6: 193-202.

Kupfer, Joseph. 1987. Privacy, autonomy, and self-concept. American Philosophical Quarterly 24: 81-89.

Lægaard, Sune. 2007. The cartoon controversy: Offence, identity, oppression? Political Studies 55: 481-498.

Lau, Terence J. 2011. Towards zero net presence. Notre Dame Journal of Law, Ethics and Public Policy 25: 237-277.

Lehavot, Keren. 2009. 'MySpace' or yours? The ethical dilemma of graduate students' personal lives on the Internet. Ethics and Behavior 19: 129-141.

Loury, Glenn C. 1994. Self-censorship in public discourse: A theory of 'political correctness' and related phenomena. Rationality and Society 6: 428-461.

Marlin, Randal. 1999. The muted bugle: Self-censorship and the press. In Interpreting censorship in Canada, ed. Klaus Petersen and Allan C. Hutchinson, 290-317. Toronto: University of Toronto Press.

McArthur, Robert L. 2001. Reasonable expectations of privacy. Ethics and Information Technology 3: $123-128$.

Mill, John Stuart. 1978 [1859]. On liberty. Ed. Elizabeth Rapaport. Indianapolis, IN: Hackett Publishing Company.

Miller, Seumas, and John Weckert. 2000. Privacy, the workplace and the Internet. Journal of Business Ethics 28: 255-265.

Mohr, Richard D. 1987. Why sex is private: Gays and the police. Public Affairs Quarterly 1: 57-81.

Moore, Adam D. 2003. Privacy: Its meaning and value. American Philosophical Quarterly 40: $215-227$.

Nagel, Thomas. 1998. Concealment and exposure. Philosophy \& Public Affairs 27: 3-30.

Øhrstrøm, Peter, and Johan Dyhrberg. 2007. Ethical problems inherent in psychological research based on Internet communication as stored information. Theoretical Medicine and Bioethics: Philosophy of Medical Research and Practice 28: 221-241.

Parent, W. A. 1983. Privacy, morality, and the law. Philosophy \& Public Affairs 12: 269-288.

Pittenger, David J. 2003. Internet research: An opportunity to revisit classic ethical problems in behavioral research. Ethics and Behavior 13: 45-60.

Pollach, Irene. 2005. A typology of communicative strategies in online privacy policies: Ethics, power and informed consent. Journal of Business Ethics 62: 221-235.

Rachels, James. 1975. Why privacy is important. Philosophy \& Public Affairs 4: 323-333.

Reiman, Jeffrey H. 1976. Privacy, intimacy, and personhood. Philosophy \& Public Affairs 6: 26-44.

Royakkers, Lambèr. 2004. Ethical issues in web data mining. Ethics and Information Technology 6: $129-140$.

Sedler, Robert A. 2012. Self-censorship and the first amendment. Notre Dame Journal of Law, Ethics and Public Policy 25: 13-45.

Spurgin, Earl W. 2006. The end of romance and the value of privacy. Public Affairs Quarterly 20: 247-265.

Tavani, Herman T. 1999. Informational privacy, data mining, and the Internet. Ethics and Information Technology 1: 137-145.

Tavani, Herman T. 2007. Philosophical theories of privacy: Implications for an adequate online privacy policy. Metaphilosophy 38: 1-22.

White, R. George. 2012. Self-censorship and the constriction of thought and discussion under modern communication technologies. Notre Dame Journal of Law, Ethics and Public Policy, 25: 123-142.

Wyatt, Anna May. 2006. Do librarians have an ethical duty to monitor patrons' Internet usage in the public library? Journal of Information Ethics 15: 70-79.

Zimmer, Michael. 2010. 'But the data is already public': On the ethics of research in Facebook. Ethics and Information Technology 12: 313-325. 